\title{
Effects of aqueous leaves extract of Ocimum gratissimum on blood glucose levels of streptozocin- induced diabetic wistar rats
}

\author{
A. Mohammed ${ }^{1 *}$, Y. Tanko ${ }^{1}$, M. A. Okasha ${ }^{1}$, R. A. Magaji ${ }^{2}$ and A. H.Yaro ${ }^{3}$ \\ ${ }^{1}$ Department of Human Physiology, Ahmadu Bello University, Zaria, Nigeria. \\ ${ }^{2}$ Department of Human Physiology, Bayero University, Kano, Nigeria. \\ ${ }^{3}$ Department of Pharmacology, Bayero University, Kano, Nigeria.
}

Accepted 13 August, 2007

\begin{abstract}
The hypoglycemic effects of aqueous leaves extract of Ocimum gratisimum was investigated in streptozocin-induced diabetic rats. A single administration of the extract at the doses of 250, 500 and $1000 \mathrm{mg} / \mathrm{kg}$ body weight was done. The aqueous extract at the dose of $500 \mathrm{mg} / \mathrm{kg}$ significantly lowered blood glucose level $(\mathrm{P}<0.05)$ of the diabetic rats by $81.3 \%$ after $24 \mathrm{~h}$ of extract administration. Preliminary phytochemical screening revealed the presence of reducing sugars, cardiac glycosides, resin, tannins, saponins, glycosides, flavonoids, glycerin and steroids. The median lethal dose $\left(L^{2} D_{50}\right)$ in rats was calculated to be $1264.9 \mathrm{mg} / \mathrm{kg}$ body weight. In conclusion, the leaves extract of 0 . gratissmm possess antidiabetic in streptozocin-induced in diabetic rats.
\end{abstract}

Key words: Ocimum gratissimm, hypoglycemic activity, streptozocin diabetes.

\section{INTRODUCTION}

Diabetes is a serious metabolic disorder with micro and macrovascular complications that results in significant morbidity and mortality (Rang et al., 1991). Chronic hyperglycemia during diabetes causes glycation of body protein that in turn leads to secondary complications affecting eyes, kidney, nerves and artery (Sharma, 1993). These may be delayed, lessened or prevented by maintaining blood glucose values close to normal. The increasing number of ageing population, consumption of calories rich diet, obesity and sedentary life style have led to a tremendous increase in number of diabetes world wide. According to $\mathrm{WHO}$ projection, the prevalence of diabetes is likely to increase by $35 \%$. Currently there are over 150 millions diabetics world wide and this is likely to increase to 300 million ore more by the year 2025 . Statistical projection about India suggests that the number of diabetic will rise from 15 million in 1995 to 57 million in the year 2025 making it the country with the highest number of diabetics in the world (King et al., 1998; Boyle et al., 2001). Therefore it is necessary to

${ }^{*}$ Corresponding author. E-mail: amohd177@hotmail.com. look for an urgent solution to manage this problem.

Basil (Ocimum spp. L) is a small shrub with many branches, commonly found in many gardens around village huts in Nigeria and planted for its medicinal uses. Originating from Central Africa and South East Asia (Simon and James, 1995), basil is probably one of the most commonly used of all herbs in cooking and there are many recipes - local and foreign that is enhanced by this minty aromatic plant. In Nigeria, about four varieties of basil are known to occur naturally in Southern and Northern part of the country. These are Ocimum suave, Ocimum gratissimum, Ocimum basilium and Ocimum camium. Local names of basil in various ethic groups include Efirin (Yoruba), neh-anwu (Ibo), ntion (Efik) and dai-doya ta gida (Hausa). Basil is believed to have significant health benefit. The leaves of African varieties are said to contain thymol oil which is regarded as highly antiseptic and it is also used to prevent mosquito bite (Agnaniet et al., 2005).

Traditionally, basil has been used as a medicinal plant in the treatment of headache, diarrhea, wart, worms and kidney function (Simon and James, 1995; Seung-Jo-Lee et al., 2004). In addition to health benefit, basil is used widely as a condiment or spice and as a source of flavor 
and which may be used in soup preparation. The present study was designed to investigate the hypoglycemic effect of aqueous leaves extracts of $O$. grasitimum in streptozocin-induced diabetes.

\section{MATERIALS AND METHODS}

\section{Chemicals}

Streptozocin (STZ) was purchased from Sigma chemicals (St Louis U.S.A). The Biphasic Isophane Insulin AS Mixtard $30 \mathrm{HM}$ Pen fills (Novo Nordisk AIS 2880 Bagsvaerd, Denmark. NAFDAC Reg no 04-1601) was used. ONE TOUCH BASIC meter (Lifescan, Inc 2001 Milpitas, CA 95035, U.S.A.) was used for the determination of blood glucose levels.

\section{Plant material}

Fresh leaves of $O$. grassitiimum were collected from Ahmadu Bello University (ABU) Main campus Zaria in the month January 2007. The plant was identified by Mal. M. Musa at the herbarium unit of Biological Science Department A.B.U., Zaria where a voucher specimen (No. 2637) has been deposited.

\section{Extract preparation}

The fresh leaves collected were dried under the shade and ground into powder. The powder $(5 \mathrm{~g})$ was boiled in $1.5 \mathrm{~L}$ of distilled water for $20 \mathrm{~min}$. The extract was cooled, filtered using a filter paper and evaporated to dryness in water bath of $60^{\circ} \mathrm{C}$. A brownish residue weighing $15.5 \%(\mathrm{w} / \mathrm{w})$ was obtained and kept in air tight bottles in a refrigerator until use.

\section{Animals}

Wistar strain albino rats of both sexes weighed between $150-200$ g,were obtained from the Animal house, Department of Pharmacology A. B.U., Zaria. The animals were kept and maintained under laboratory condition of temperature, humidity and light. The animals were divided into extract treated groups and the control groups. All the animals were fasted for $12 \mathrm{~h}$, but were allowed free access to water, before commencement of the experiments.

\section{Phytochemical screening}

The aqueous extracts obtained were subjected to preliminary phytochemical screening to identify the chemical constituents. The methods of analysis employed were those described by Brain and Turner (1975).

\section{Acute toxicity study}

The lethal doses $\left(L_{50}\right)$ of the plant extract was determined by method of Lorke (1983) using 13 rats. In the first phase, rats were divided into 3 groups of 3 rats each and were treated with the aqueous extract of the plant at doses of 10,100 and $1000 \mathrm{mg} / \mathrm{kg}$ bodyweight intraperitoneal. They were observed for $24 \mathrm{~h}$ for signs of toxicity. In the second phase, 4 rats were divided into 4 groups of 1 rat each and were also treated with the aqueous extract at doses of $600,1000,1600$ and $2900 \mathrm{mg} / \mathrm{kg}$ bodyweight (i.p).The median lethal dose $\left(\mathrm{LD}_{50}\right)$ was calculated using the second phase.

\section{Induction of diabetes}

Diabetes mellitus was induced by single intraperitoneal dose of 60 $\mathrm{mg} / \mathrm{kg}$ of streptozocin dissolved in $0.1 \mathrm{~m}$ fresh cold citrate buffer $\mathrm{pH}$ 4.5 into $12 \mathrm{~h}$-fasted rats. On the third day of STZ-injection, the rats were fasted for $6 \mathrm{~h}$ and blood was taken from tail artery of the rats (Burcelin et al., 1995). Rats with moderate diabetes having hyperglycemia (that is, with blood glucose of $250-400 \mathrm{mg} / \mathrm{dl}$ ) were taken for the experiment. The diabetic rats were then divided randomly in the different groups.

\section{Experimental design}

In the experiment, a total of 25 rats were used, the rats were divided into 5 groups of 5 rats each. Group 1 has normal rats; Groups 2 to 5 have diabetic; Group 2 rats were given Biphasic Isophane insulin 6 i.u/kg, while Groups 3, 4 and 5 were extract treated group at 250, 500 and $1000 \mathrm{mg} / \mathrm{kg}$ bodyweight, respectively.

\section{Determination of blood glucose levels}

All blood samples were collected from the tail artery of the rats at interval. Determination of the blood levels was done by the glucoseoxidase principle (Beach and Turner, 1958) using the ONE TOUCH Basic (lifescan, mulpital CA instrument) and the result were expressed as mg/dl (Rheney and Kirk, 2000).

\section{Statistical analysis}

Blood glucose levels for each group were expressed in $\mathrm{mg} / \mathrm{dl}$ as mean \pm SEM. The data were statistically analyzed using ANOVA with multiply comparisons versus control group. The values of $\mathrm{p}<0.05$ were considered as significant (Duncan et al., 1997).

\section{RESULTS}

\section{Phytochemical analysis}

Freshly prepared extracts were subjected to preliminary phytochemical screening test for various constituents. This revealed the presence of reducing sugars, cardiac glycosides, resin, tannins, saponins, glycosides, flavornoids, glycerin and steroids.

\section{Acute toxicity study $\left(\mathrm{LD}_{50}\right)$}

The sign of toxicity were first noticed after $2-4 \mathrm{~h}$ of extract administration. There was decreased locomotor activity and decreased in sensitivity to touch. Also there was decreased feed intake and prostration after $12 \mathrm{~h}$ of extract administration. The median lethal dose $\left(L_{50}\right)$ in rats was calculated to be $1264.9 \mathrm{mg} / \mathrm{kg}$ body weight. 
Table 1. Effect of aqueous leaves extract of Ocimum gratissimum on streptozocin-induced diabetic Wistar rats.

\begin{tabular}{|l|c|c|c|c|c|}
\hline \multirow{2}{*}{ Treatment } & \multicolumn{5}{|c|}{ Blood glucose levels $\mathbf{( m g} / \mathbf{d l} \mathbf{l})$} \\
\cline { 2 - 6 } & $\mathbf{0 ~ h}$ & $\mathbf{2 ~ h}$ & $\mathbf{4} \mathbf{~ h}$ & $\mathbf{8 ~ h}$ & $\mathbf{2 4} \mathbf{~ h}$ \\
\hline Control & $399.8 \pm 42.81$ & $380.4 \pm 45.84$ & $371.6 \pm 29.59$ & $267.0 \pm 43.0$ & $358.4 \pm 49.13$ \\
Insulin & $382.8 \pm 10.01$ & $240.4 \pm 38.42^{\mathrm{a}}$ & $328.0 \pm 35.94^{\mathrm{ns}}$ & $394.8 \pm 13.06^{\text {ns }}(-3.13 \%)$ & $388.0 \pm 12.59^{\text {ns }}(-1.36 \%)$ \\
$250 \mathrm{mg} / \mathrm{kg}$ & $389.4 \pm 51.04$ & $396.6 \pm 54.04^{\mathrm{ns}}$ & $308.6 \pm 63.69^{\text {ns }}$ & $412.2 \pm 75.87^{\text {ns }}(+5.86 \%)$ & $266.6 \pm 64.59^{\text {ns }}(-31.69 \%)$ \\
$500 \mathrm{mg} / \mathrm{kg}$ & $373.2 \pm 49.07$ & $424.4 \pm 30.85^{\mathrm{ns}}$ & $338.6 \pm 27.28^{\mathrm{ns}}$ & $72.2 \pm 27.90^{\mathrm{a}}(-80.65 \%)$ & $70.8 \pm 20.67^{\mathrm{a}}(-81.03 \%)$ \\
$1000 \mathrm{mg} / \mathrm{kg}$ & $379.6 \pm 30.80$ & $299.6 \pm 38.06 \mathrm{~ns}$ & $338.6 \pm 27.28 \mathrm{~ns}$ & $229.8 \pm 49.03 \mathrm{~ns}(-39.46 \%)$ & $232.6 \pm 30.14 \mathrm{~ns}(38.72 \%)$ \\
\hline
\end{tabular}

${ }^{\mathrm{a}} \mathrm{P}<0.05$.

${ }^{\mathrm{n}}$ Not significant.

*Percentage glycemic change.

Glycemic change $(\%)=[($ Glucose concentration $(2,4,8$ or 24$)-$ fasting blood glucose $) /$ Fasting blood glucose $] \times 100$.

\section{Blood glucose levels of Wistar rats}

The results of the blood glucose levels are shown in Table 1. After $2 \mathrm{~h}$ of treatment, only insulin showed a significant $(p<0.05)$ decrease in blood glucose levels compared to control. After $4 \mathrm{~h}$, there was no significant change in any of the treatments given. After 8 and $24 \mathrm{~h}$, there was a significant decrease only in the blood glucose levels of the group treated with $500 \mathrm{mg} / \mathrm{Kg}$ body weight of the extract.

\section{DISCUSSION}

Many secondary metabolites participate in a variety of antidiabetic functions in vivo (Kako et al., 1997). However, there is paucity of literature on the anti-diabetic potential of this plant. The glycemic change in blood glucose level of diabetic rat at different time intervals after intraperitoneal administration of aqueous leaves extract of $O$. grassitimum at the doses of 250,500, and 1000 $\mathrm{mg} / \mathrm{kg}$ is shown in Table 1 . In relation to the diabetes rats that received 250 and $1000 \mathrm{mg} / \mathrm{kg}$ bodyweight of the leave extracts of $O$. gratissimum, there was no significant change in the blood glucose levels when compared to the control group. In regard to the dose of $500 \mathrm{mg} / \mathrm{kg}$ of $O$. gratissimum, it significantly $(\mathrm{P}<0.05)$ lowered the blood glucose level when compared to control after 8 and $24 \mathrm{~h}$ of extract administration. The dose of $500 \mathrm{mg} / \mathrm{kg}$ was found to be more effective with percentage glycemic change of 80.6 and $81.3 \%$ after 8 and 24 h, respectively. In regard to the dose of $250 \mathrm{mg} / \mathrm{kg}$, the percentage glycemic change showed an increase after $8 \mathrm{~h}$ of extract administration with $5.86 \%$ and after $24 \mathrm{~h}$ there was a decrease in the percentage $(-31.69 \%)$ glycemic change. Also in relation to the dose of $1000 \mathrm{mg} / \mathrm{kg}$, the percentage glycemic change after 8 and $24 \mathrm{~h}$ of extract administration showed a decreased in the percentage glycemic change of 39.46 and $38.72 \%$, respectively.

In conclusion, the present study showed that aqueous leaves extracts of $O$. gratissimum possessed antidiabetic properties which suggest the presence of biologically active components which may be worth further investigation and elucidation. The effective antidiabetic dose was found to be $500 \mathrm{mg} / \mathrm{Kg}$ body weight. Further studies are currently under way to isolate and characterized the active components of the crude extract of this plant.

\section{ACKNOWLEDGEMENTS}

The authors of this work wish to acknowledge the technical assistance of Bala Mohammed and Nura Mohammed of the Department of Physiology, Faculty of Medicine Ahmadu Bello University, Zaria, Nigeria.

\section{REFERENCES}

Agnaniet $\mathrm{H}$, Arguillet J, Bessieve JM, Menut C (2005). Aromatic plant of tropical Central Africa. Part XL-VIL Chemical and Biological investigation of essential oil of Ocimum species from Gabon. J. Ess. Oil Res. Abstract.

Beach EF, Turner JJ (1958). An enzymatic method for glucose determination uptake in body fluids. Clin Chem. 4: 462-468.

Boyle JP, Honey C, Honeycutt AA, Narayan KM, Hoerger TJ, Geisis LS, Chen $\mathrm{H}$, Thompson TJ ( 2001). Projection of diabetes burden through 2025: Impact of changing demography and disease prevalence in the U.S. Diabetes Care 24: 1936-1940.

Brain KR, Turner TD (1975). The Practical Evaluation of Phytopharmaceuticals, Wright Scientechnica, Bristol, pp. 57-58.

Burcelin R, Eddouks M, Maury J, Kande J, Assan R, Girard J (1995). Excessive glucose production, rather than Insulin resistance, account for hyperglycemia in recent onset streptozocin-diabetic rats. Diabetologia 35: 283-290.

Duncan RC, Knapp RG, Miller MC (1977). Test of hypothesis in population means. In: Introductory Biostatistics for the health sciences. John Wiley and Sons Inc. NY pp. 71-96.

Kako M, Miura T, Nishiyama Y, Ichimaru M, Moriyasu M, Kato A (1997). Hypoglycemic Activity of Some Triterpenoid Glycosides. J. Nat. Prod. 60:604-605.

King H, Aubert RE, Herma WH (1998). Global burden of diabetes 19952025: Prevalence, numerical estimates and projection. Diabetes Care 21: 1414-1431.

Lorke D (1983). A New Approach to Practical Acute Toxicity Testing Arch. Toxicol. pp. 275-287.

Rang HP, Dale MM, Ritters, JM (1991). The endocrine pancreas and the control of blood glucose: In Barbara Simmons, Susan Beasley. Eds. Pharmacology, $3^{\text {rd }}$ U.K, Longman Group Ltd, pp. 403-410.

Rheney CC, Kirk KK (2000). Performance of three blood glucose meters. Ann. Pharmacother. 34(3): 317-321. 
Seung-Joo-Lee KU, Takayuki S, Kwang-Guen L (2004). Identification of volatile components in basil (ocimum basilicum) and thyme leaves (thymus vulgaris) and their antioxidant properties, Food Chemistry 91: 131-137.

Sharma AK (1993).Diabetes mellitus and its complication: An update ( $1^{\text {st }}$ Macmillan, New Delhi).
Simon A, James E (1995). Basil New Crop Fact Sheet. 